agriTECH, 40 (4) 2020, 322-331

\title{
Studi Komparasi: Produksi Bioetanol Nira Batang Kelapa Sawit oleh Flokulan dan Non- Flokulan Saccharomyces cerevisiae
}

\author{
Comparative Study: Bioethanol Production from Oil Palm Trunk Sap by Flocculant and Non-Flocculant \\ Saccharomyces Cerevisiae
}

\section{Kafidul Ulum ${ }^{1}$, Indria Purwantiningrum ${ }^{1}$, Retno Dwi Yustina ${ }^{2}$, Untung Murdiyatmo ${ }^{1}$, Agustin Krisna Wardani ${ }^{*}$}

\author{
1]urusan Teknologi Hasil Pertanian, Fakultas Teknologi Pertanian, Universitas Brawijaya, \\ Jl. Veteran, Malang 65145, Indonesia \\ 2PT. Sampoerna Agro, Tbk, Jl. Basuki Rachmat No.788, Talang Aman, Kemuning, Kota Palembang, \\ Sumatera Selatan 30127, Indonesia \\ *Penulis korespondensi: Agustin Krisna Wardani, E-mail: agustinwardani@ub.ac.id
}

Tanggal submisi: 15 November 2018; Tanggal penerimaan: 8 April 2020

\begin{abstract}
ABSTRAK
Produksi bioetanol dari nira batang kelapa sawit pada penelitian ini dilakukan melalui fermentasi dengan menggunakan dua jenis strain Saccharomyces cerevisiae, yaitu flokulan Saccharomyces cerevisiae NCYC-1195 dan non-flokulan Saccharomyces cerevisiae Kyokai 7 (NCYC-479). Untuk melihat pengaruh sumber nitrogen terhadap kinerja yeast dalam memproduksi etanol, ditambahkan urea sebagai sumber nitrogen selama fermentasi. Tujuan penelitian ini adalah untuk mendapatkan strain Saccharomyces cerevisiae dan konsentrasi urea yang tepat untuk memproduksi etanol tertinggi. Konsentrasi urea yang digunakan adalah $0 \%, 0,1 \%, 0,2 \%$, dan $0,3 \%(b / v)$. Hasil penelitian menunjukkan bahwa etanol tertinggi yaitu sebesar $4,86 \%(\mathrm{v} / \mathrm{v})$ dengan yield etanol sebesar $0,52(\mathrm{~g} / \mathrm{g})$ diperoleh dari fermentasi nira batang kelapa sawit oleh non-flokulan Saccharomyces cerevisiae Kyokai 7 (NCYC479) tanpa adanya penambahan urea.
\end{abstract}

Kata kunci: Bioethanol; nira kelapa sawit; flokulan; Saccharomyces cerevisiae; urea

\begin{abstract}
Two types of yeast were used for bioethanol production from oil palm trunk sap, the flocculant Saccharomyces cerevisiae NCYC-1195 and non-flocculant Saccharomyces cerevisiae Kyokai 7 (NCYC-479). Flocculant Saccharomyces cerevisiae is yeast that has ability to aggregate into flocks which precipitate rapidly in culture medium. The effect of urea as a nitrogen source was also investigated in this study. Some concentrations of urea were added i.e. $0 \%, 0.1 \%, 0.2 \%$, and $0.3 \%(\mathrm{w} / \mathrm{v})$ during fermentation. The purpose of this study is to obtain the best condition by strain of Saccharomyces cerevisiae and urea concentration for the highest ethanol production. The highest ethanol production and yield was obtained at $4.86 \%(\mathrm{v} / \mathrm{v})$ and $0.52(\mathrm{~g} / \mathrm{g})$ respectively, by nonflocculant Saccharomyces cerevisiae Kyokai 7 (NCYC-479) without the addition of urea.
\end{abstract}

Keywords: Bioethanol; oil palm trunk sap; Saccharomyces cerevisiae; urea 


\section{PENDAHULUAN}

Kebutuhan energi dunia akan terus meningkat sejalan dengan pertambahan penduduk dan pertumbuhan ekonomi. Peningkatan kebutuhan bahan energi terutama bahan bakar fosil tersebut telah menyebabkan penurunan cadangan minyak dunia sampai tahun 2050 (Allaudin dkk., 2010; Sultana dkk., 2017). Menurut data BPS dalam Sinaga (2012), produksi BBM Indonesia berada di bawah jumlah kebutuhan untuk konsumsi nasional. Sejak tahun 1996 hingga 2012 produksi minyak mentah Indonesia mengalami penurunan sebesar 57\%, sedangkan perkembangan jumlah kendaraan bermotor di Indonesia yang mengalami kenaikan pesat hingga $649 \%$. Hal ini menyebabkan pemerintah harus mengimpor BBM dari luar negeri untuk menutupi defisit kebutuhan nasional tersebut. Menurut Direktorat ESDM (2017), Indonesia masih mengimpor BBM sebesar 22,801,063 kiloliter pada tahun 2016, sehingga perlu dicari sumber energi alternatif dari bahan terbarukan.

Nira batang kelapa sawit mempunyai kandungan total gula sebesar 96,7 g/L hingga $111 \mathrm{~g} / \mathrm{L}$ (Mori, 2007; Kosugi dkk., Yamada dkk., 2010). Selain gula, nira ini juga mengandung asam amino, asam organik, vitamin dan mineral. Kandungan gula yang tinggi, asam amino, asam organik, vitamin dan mineral yang terdapat di dalam nira, serta jumlah yang melimpah, hal ini membuat nira batang kelapa sawit sangat potensial untuk dimanfaatkan sebagai bahan baku etanol.

Produksi bioetanol secara efisien dapat diperoleh dengan beberapa cara yaitu seleksi mikroorganisme yang sesuai, bahan baku yang murah dan ketersediaan yang melimpah, dan proses fermentasi yang optimal. Penggunaan Saccharomyces cerevisiae dalam proses fermentasi gula menjadi etanol telah banyak dilakukan, baik dari kelompok flokulan maupun non-flokulan Saccharomyces cerevisiae. Flokulan Saccharomyces cerevisiae adalah yeast yang memiliki kemampuan membentuk flok atau gumpalan sel selama pertumbuhannya dalam medium (Azhar dkk, 2017). Hal ini menjadi faktor penting dalam proses purifikasi bioetanol karena dapat menghilangkan tahapan sentrifugasi sehingga efisiensi produksi meningkat (Domingues dkk, 2000). Sedangkan non- flokulan Saccharomyces cerevisiaetidak mempunyai kemampuan untuk membentuk flok, sehingga diperlukan proses tambahan untuk purifikasi.

Produksi etanol dari nira batang kelapa sawit belum banyak diekplorasi sedangkan bahan tersebut sangat potensial digunakan sebagai bahan baku yang murah disamping memiliki kandungan gula yang cukup tinggi. Pada penelitian ini produksi etanol dilakukan dengan menggunakan 2 jenis yeast yaitu flokulan dan non-flokulan Saccharomyces cerevisiae untuk memfermentasi nira batang kelapa sawit menjadi etanol. Pengamatan pengaruh penambahan sumber nitrogen (urea) selama fermentasi juga dilakukan untuk mendapatkan hasil terbaik yaitu menghasilkan yield etanol tertinggi.

\section{METODE PENELITIAN}

\section{Bahan}

Bahan baku utama yang digunakan dalam penelitian ini adalah nira batang kelapa sawit yang diperoleh dari pengepresan limbah batang kelapa sawit PT. Sampoerna Agro, Tbk, Palembang. Isolat yang digunakan adalah flokulan Saccharomyces cerevisiae (NCYC-1195) diperoleh dari National Research Institute of Brewing, Hiroshima, Jepang, dan non-flokulan Saccharomyces cerevisiae Kyokai no 7 (NCYC-479) diperoleh dari National Collection of Yeast Cultures, Norwich, United Kingdom. Isolat ditumbuhkan pada media sintetik yang mengandung glukosa (Sigma, USA), yeast extract (Sigma, USA) dan pepton (Sigma, USA). Bahan kimia yang digunakan yaitu $\mathrm{H}_{2} \mathrm{SO}_{4}$ (Sigma, USA), $\mathrm{NaOH}$ (Sigma, USA), 3,5-dinitrosalisilic acid (DNS) (Sigma, USA), urea (Merck, USA), $\mathrm{KH}_{2} \mathrm{PO}_{4}$ (Sigma, USA), $\left(\mathrm{NH}_{4}\right)_{2} \mathrm{SO}_{4}$ (Sigma, USA), $\mathrm{MgSO}_{4} \cdot 7 \mathrm{H}_{2} \mathrm{O}$ (Sigma, USA), Na-K Tartarat (Sigma, USA), fenol kristal (Sigma, USA), $\mathrm{Na}_{2} \mathrm{SO}_{3}$ (Sigma, USA), NaCl p.a (Sigma, USA), EDTA (Sigma, USA).

\section{Pengamatan Flokulan dan Non-Flokulan Saccharomyces cerevisiae Menggunakan Mikroskop Cahaya}

Untuk mengetahui bentuk sel, maka dilakukan pembuatan preparat basah flokulan dan non-flokulan Saccharomyces cerevisiae. Satu ose inokulum Saccharomyces cerevisiae dari media agar miring PGYA diletakkan dalam gelas preparat yang telah ditambahkan 1 tetes akuades dan selanjutnya ditambahkan safranin untuk memperjelas morfologi yeast.

\section{Kurva Pertumbuhan Saccharomyces cerevisiae}

Untuk mengetahui kurva pertumbuhan S. cerevisiae Kyokai 7 dan flokulan S. cerevisiae digunakan dua jenis medium sintetik yaitu YPD (glukosa $20 \mathrm{~g} / \mathrm{L}$, yeast extract $10 \mathrm{~g} / \mathrm{L}$, pepton $20 \mathrm{~g} / \mathrm{L}$ ), untuk $S$. cerevisiae Kyokai 7 dan YM (glukosa $10 \mathrm{~g} / \mathrm{L}$, yeast extract $3 \mathrm{~g} / \mathrm{L}$, pepton $5 \mathrm{~g} / \mathrm{L}$, malt extract $3 \mathrm{~g} / \mathrm{L}$ ) untuk flokulan $S$. cerevisiae. Masingmasing 5\% (v/v) kultur ditumbuhkan pada medium sintetik YPD dan YM kemudian diamati Optical density (OD) menggunakan spektrofotometer dengan panjang gelombang $(\lambda) 600 \mathrm{~nm}$ setiap 4 jam selama 24 jam. 


\section{Aktivasi dan Pembuatan Stok Kultur}

Aktivasi kultur dilakukan dengan menumbuhkan kultur murni S. cerevisiae ke dalam media broth YPD, diinkubasi selama 48 jam pada suhu $30^{\circ} \mathrm{C}$ dan $150 \mathrm{rpm}$. Stok kultur dalam gliserol dibuat dengan memasukkan stok gliserol $60 \%$ dan kultur hasil aktivasi dari media YPD dengan perbandingan 1:1, kemudian disimpan dalam deep freezer suhu $-80^{\circ} \mathrm{C}$.

\section{Pembuatan Kultur Starter Saccharomyces cerevisiae}

Lima persen $(5 \%, v / v)$ kultur yang telah diremajakan selama 24 jam dimasukkan dalam $100 \mathrm{ml}$ medium YPD dan diinkubasi pada suhu $30^{\circ} \mathrm{C}, 150 \mathrm{rpm}$ selama 16 jam untuk flokulan S. cerevisiae dan 20 jam untuk non-flokulan S. cerevisiae Kyokai 7.

\section{Produksi Nira Batang Kelapa Sawit}

Nira batang kelapa sawit diperoleh dengan cara mengepres parutan batang kelapa sawit menggunakan alat press hydrolic dengan tekanan $80 \mathrm{mpa}$. Nira hasil pengepresan disentrifugasi $6000 \mathrm{rpm} 15$ menit untuk memisahkan nira dengan pengotor. Supernatan hasil sentrifugasi disimpan pada suhu $20^{\circ} \mathrm{C}$ untuk mencegah penurunan gula (Kosugi, 2010).

\section{Fermentasi Etanol}

Sebanyak 5\% (v/v) yeast ditumbuhkan pada medium nira batang kelapa sawit yang telah disiapkan dengan konsentrasi urea $0 \%, 0,1 \%, 0,2 \%$, dan $0,3 \%$ $(\mathrm{b} / \mathrm{v})$. Fermentasi dilakukan pada shaker waterbath pada suhu $30^{\circ} \mathrm{C}, 120 \mathrm{rpm}$ selama 72 jam. Selanjutnya dilakukan analisa terhadap Optical density (OD) sel, $\mathrm{pH}$, gula reduksi setiap 24 jam dan analisa kadar etanol pada jam ke-0, 24, 48 dan 72. Analisa kadar etanol dilakukan dengan menggunakan gas chromatography.

\section{HASIL DAN PEMBAHASAN}

\section{Karakteristik Flokulan Saccharomyces cerevisiae (NCYC-1195) dan Non-flokulan Saccharomyces cerevisiae Kyokai 7 NCYC-479}

Pada penelitian ini, Saccharomyces serevisiae yang digunakan terdiri dari dua strain yang berbeda, yaitu flokulan strain dan non-flokulan strain. Flokulan Saccharomyces cerevisiae merupakan yeast yang mempunyai kemampuan membentuk gumpalan sel (flok) kemudian mengendap dengan cepat dalam medium pertumbuhannya (Kida dkk., 1991), sedangkan non-flokulan tidak mempunyai kemampuan untuk membentuk gumpalan. Pengamatan morfologi

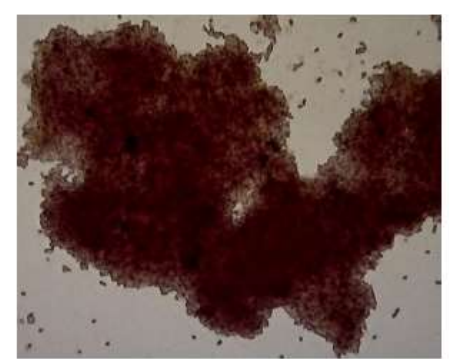

(a)

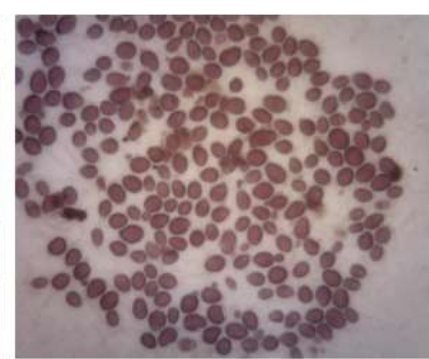

(b)
Gambar 1. Pengamatan Saccharomyces cerevisiae dengan mikroskop cahaya perbesaran 1000X, (a) NCYC-1195 (flokulan),

(b) Kyokai 7 NCYC-479 (non-flokulan)

Saccharomyces cerevisiae NCYC-1195 dan Kyokai 7 NCYC-479 menggunakan mikroskop dengan perbesaran 1000x. Untuk mempertajam bentuk Saccharomyces cerevisiae dilakukan pewarnaan dengan safranin. Penampakan sel Saccharomyces cerevisiae NCYC-1195 dan Kyokai 7 NCYC-479 melalui pengamatan di bawah mikroskop cahaya ditunjukkan pada Gambar 1.

Gambar 1 menunjukkan sel Saccharomyces cerevisiae NCYC-1195 (flokulan) dan Kyokai 7 NCYC479 (non-flokulan) mempunyai morfologi yang sama, yaitu sama-sama berbentuk bulat. Hal ini sesuai dengan pengamatan pada sel Kyokai 7 NCYC-479 (non-flokulan) menunjukkan sel berbentuk bulat, berukuran besar dan tidak berhimpitan antar sel (terdapat jarak antar sel), sedangkan pada sel NCYC-1195 (flokulan) sel tampak bulat, berukuran kecil serta membentuk sel yang saling berdekatan. Fenomena ini disebabkan karena melekatnya flokulin pada dinding sel yang satu dengan a-manan karbohidrat dari sel yang lain (Domingues, 2000).

\section{Pola Pertumbuhan Flokulan Saccharomyces cerevisiae (NCYC-1195) dan Non-flokulan Saccharomyces cerevisiae Kyokai 7 (NCYC-479)}

Pertumbuhan Saccharomyces cerevisiae diamati setiap 4 jam selama 24 jam dengan membaca tingkat kekeruhan (optical density, OD) medium pada panjang gelombang $600 \mathrm{~nm}$. Kurva pertumbuhan flokulan dan non-flokulan Saccharomyces cerevisiae disajikan pada Gambar 2. Kurva pertumbuhan menunjukkan flokulan dan non-flokulan Saccharomyces cerevisiae dapat tumbuh dengan baik yang ditandai dengan meningkatnya nilai OD seiring meningkatnya waktu pertumbuhan pada medium tersebut. Peningkatan jumlah sel ini terjadi akibat adanya pemanfaatan medium yang kaya akan sumber karbon dan nitrogen oleh Saccharomyces cerevisiae.

Gambar 2 menunjukkan bahwa flokulan Saccharomyces cerevisiae (NCYC-1195) mencapai fase lag (adaptasi) pada jam ke-0 sampai jam ke-2 dan non- 


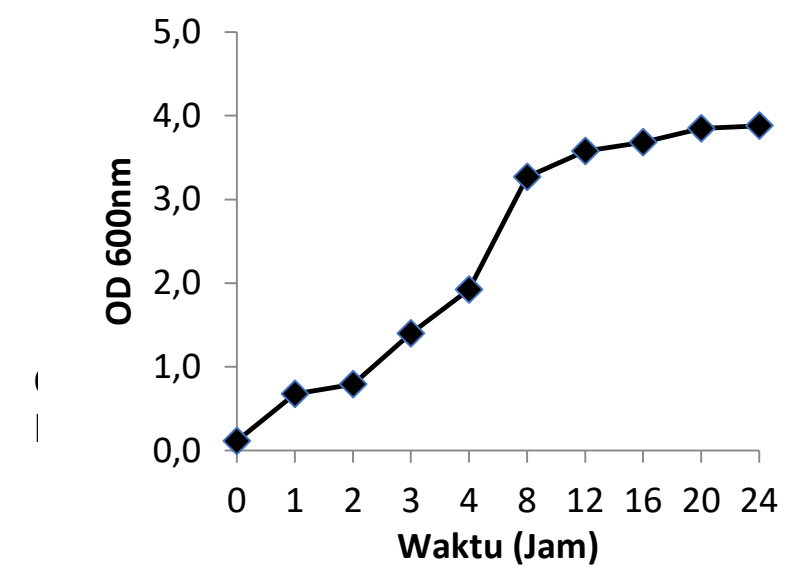

a)
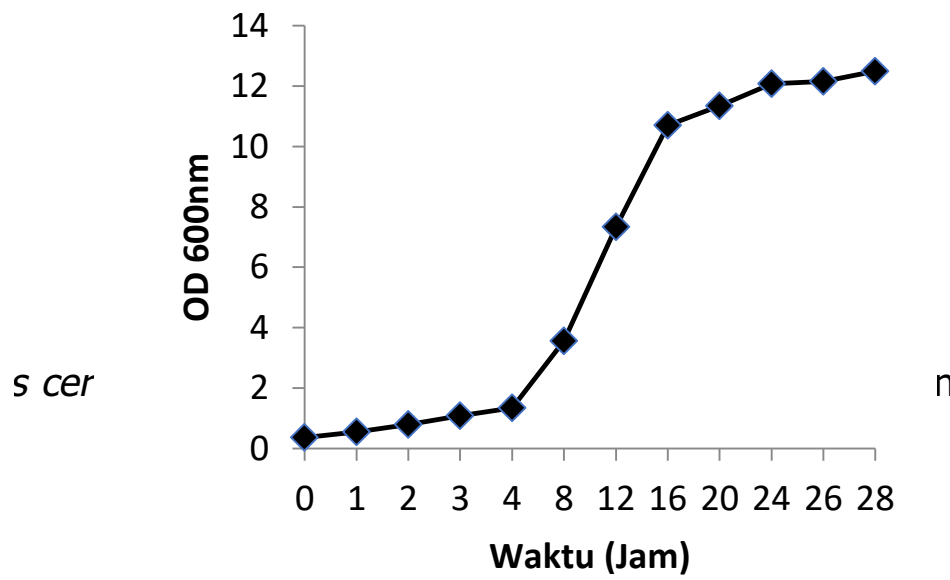

b)

Gambar 2. Kurva pertumbuhan Saccharomyces cerevisiae (a) flokulan (NCYC-1195), (b) non-flokulan Kyokai 7 (NCYC-479)

flokulan Saccharomyces cerevisiae Kyokai 7 (NCYC-479) pada jam ke-0 sampai jam ke-4. Selanjutnya fase log flokulan Saccharomyces cerevisiae dicapai pada jam ke-2 sampai ke-16 dan non-flokulan Saccharomyces cerevisiae pada jam ke-4 sampai jam ke-20. Pada fase ini sel mengalami pertumbuhan optimal karena terjadi katabolisme substrat dalam jumlah besar yang digunakan untuk pertumbuhan, sintesa enzim dan sintesa senyawa lainnya. Fase selanjutnya yaitu fase stasioner dialami oleh flokulan Saccharomyces cerevisiae (NCYC-1195) pada jam ke-16 hingga ke-24 dan non-flokulan Saccharomyces cerevisiae Kyokai 7 (NCYC-479) pada jam 20 hingga ke-28. Pada kondisi ini jumlah sel tidak mengalami peningkatan bahkan cenderung konstan karena menurunnya ketersediaan substrat. Menurut Khongsey dkk. (2010), fase stasioner Saccharomyces cerevisiae terjadi pada jam ke-12 hingga jam ke-24 tergantung pada konsentrasi awal sel. Konsentrasi awal sel tertinggi adalah pada saat awal fase stasioner atau puncak fase logaritmik. Oleh karena itu, pada penelitian ini kultur starter yang digunakan untuk fermentasi etanol dari nira batang kelapa sawit adalah flokulan Saccharomyces cerevisiae (NCYC-1195) yang berumur 16 jam dan non-flokulan Saccharomyces cerevisiae Kyokai 7 (NCYC-479) yang berumur 20 jam, fase dimana konsentrasi sel paling maksimal.

\section{Pengaruh Penambahan Urea Terhadap Konsumsi Gula oleh Flokulan Saccharomyces cerevisiae NCYC-1195 dan Non-flokulan Saccharomyces cerevisiae Kyokai 7 (NCYC-479)}

Nutrisi makro yang diperlukan mikroba terdiri dari unsur $\mathrm{C}$ dan $\mathrm{N}$. Unsur $\mathrm{C}$ diperoleh dari glukosa yang terkandung dalam nira batang kelapa sawit, sedangkan unsur $\mathrm{N}$ diperoleh dari penambahan urea.
Menurut Hermawan dkk. (2000) konsentrasi dan jenis sumber nitrogen akan mempengaruhi nilai $\mathrm{pH}$ medium, pertumbuhan dan aktivitas mikroorganisme dalam proses fermentasi. Dalam penelitian ini, digunakan 4 macam konsentrasi urea yang berbeda $(0 \% ; 0,1 \%$; $0,2 \%$; dan $0,3 \%(\mathrm{~b} / \mathrm{v}))$ dan profil konsumsi gula yang dipengaruhi keempat macam konsentrasi urea tersebut yang ditunjukkan pada Gambar 3.

Pada Gambar 3 bisa diketahui bahwa dari semua konsentrasi urea yang ditambahkan $(0,1 \% ; 0,2 \%$ dan $0,3 \%)$ pada medium fermentasi nira mempunyai tren konsumsi gula yang sama terhadap medium fermentasi tanpa diperkaya urea (0\%). Konsentrasi urea yang ditambahkan sebagai sumber nitrogen tidak terlalu berpengaruh terhadap konsumsi gula baik pada nonflokulan Saccharomyces cerevisiae Kyokai 7 (NCYC-479) dan flokulan Saccharomyces cerevisiae NCYC-1195. Respon penambahan urea $0 \% ; 0,1 \% ; 0,2 \%$ dan $0,3 \%$ terhadap konsumsi gula oleh Saccharomyces cerevisiae Kyokai 7 NCYC-479 (non-flokulan) secara berturut-turut sebesar 9,39\%; 9,29\%; 9,09\% dan 9,24\%. Sedangkan pada Saccharomyces cerevisiae NCYC-1195 (flokulan), konsumsi gula secara berturut-turut sebesar $8,77 \%$; 8,91\%; 8,94\%, dan 9,45\%. Pada data Gambar 3 bisa diketahui bahwa dalam medium nira batang kelapa sawit tidak semua gula dapat terfermentasi, baik oleh Saccharomyces cerevisiae NCYC-1195 (flokulan) maupun oleh Saccharomyces cerevisiae Kyokai 7 NCYC479 (non-flokulan), hal ini diduga terjadi karena pada nira batang kelapa sawit terdapat gula C-5 yang tidak bisa dimanfaatkan oleh Saccharomyces cerevisiae. Carl dkk. (2000) menyatakan Saccharomyces cerevisiae mampu memfermentasi berbagai jenis gula yaitu heksosa atau D-glukosa, D-fruktosa, dan D-manosa. Sukrosa, maltosa, dan D-galaktosa juga dapat difermentasi, 


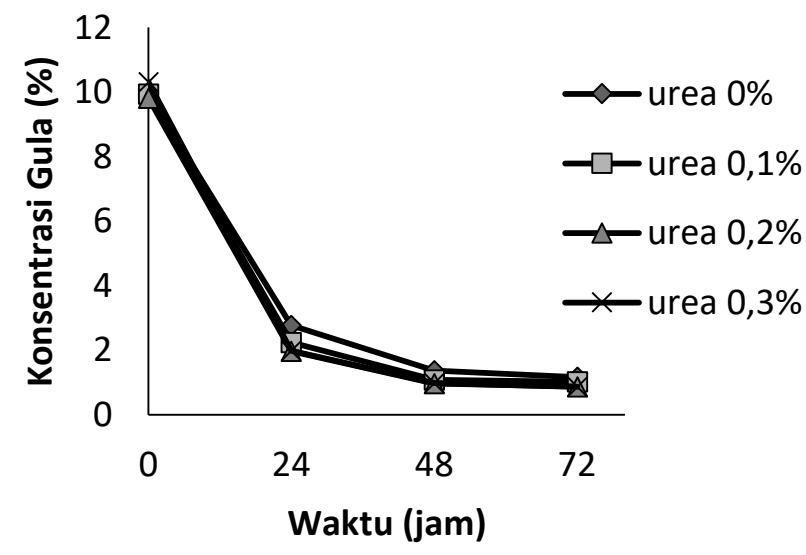

a)

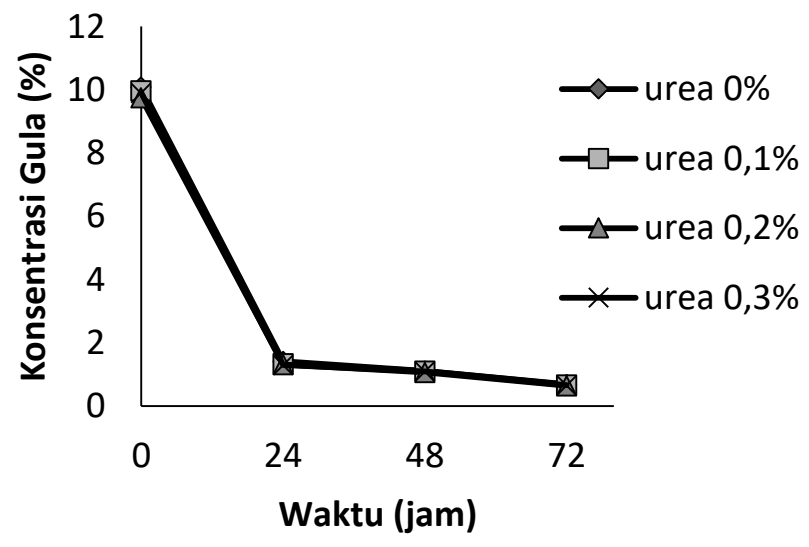

b)

Gambar 3. Pengaruh penambahan urea terhadap konsumsi gula oleh: (a) flokulan Saccharomyces cerevisiae (NCYC-1195), (b) non-flokulan Saccharomyces cerevisiae Kyokai 7 (NCYC-479)

tetapi gula dalam bentuk $L$ dan gula C- 5 seperti xilosa dan arabinosa tidak dapat difermentasi. Penurunan gula selama proses fermentasi terjadi karena gula digunakan sebagai substrat utama oleh Saccharomyces cerevisiae untuk sintesis massa sel, pemeliharaan sel, dan produksi berbagai macam metabolit seperti etanol, gliserol, asam asetat, asam laktat, dan asam suksinat (Carl dkk., 2000). Saccharomyces cerevisiae memproduksi etanol dari glukosa melalui jalur Embden Meyerhof Parnas (EMP), dimana satu molekul glukosa dimetabolisme, dan dua molekul piruvat dihasilkan (Madigan dkk., 2000).

\section{Pengaruh Penambahan Urea terhadap Pertumbuhan Sel oleh Flokulan Saccharomyces cerevisiae NCYC-1195 dan Non-flokulan Saccharomyces cerevisiae Kyokai 7 NCYC-479}

Pengaruh penambahan urea terhadap pertumbuhan sel pada Saccharomyces cerevisiae disajikan pada Gambar 4. Berdasarkan data tersebut terlihat bahwa konsentrasi urea yang ditambahkan sebagai sumber nitrogen tidak terlalu berpengaruh terhadap pertumbuhan sel baik pada pertumbuhan Saccharomyces cerevisiae NCYC-1195 (flokulan) maupun Saccharomyces cerevisiae Kyokai 7 NCYC479 (non-flokulan). Pada Gambar 4 terlihat bahwa dari semua konsentrasi urea yang ditambahkan $(0,1 \% ; 0,2 \%$ dan $0,3 \%$ ) pada medium fermentasi nira tidak memiliki pengaruh terhadap pertumbuhan sel, sama seperti pada pola pertumbuhan sel yang tidak ditambahkan urea $(0 \%)$.

Saccharomyces cerevisiae NCYC-1195 (flokulan) dan Kyokai 7 NCYC-479 mengalami pertumbuhan secara signifikan selama fermentasi 24 jam kemudian sel mengalami fase stasioner pada fermentasi 24 jam hingga 72 jam. Selama fase eksponensial, sel tumbuh sangat cepat dan jumlah sel bertambah mengikuti kurva

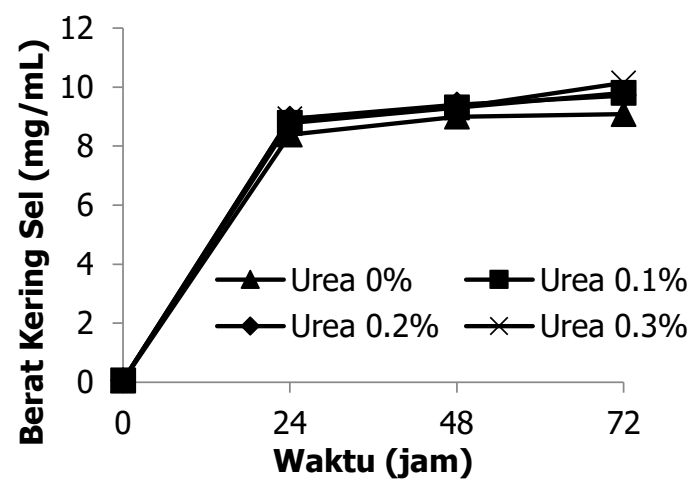

a)

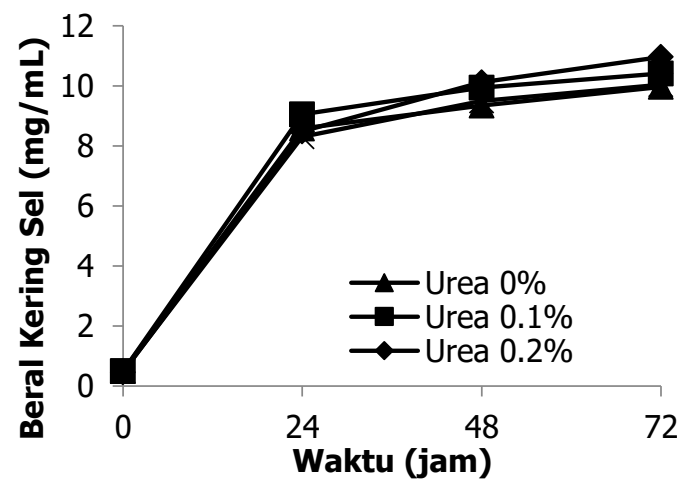

b)

Gambar 4. Pengaruh penambahan urea terhadap pertumbuhan sel Saccharomyces cerevisiae (a) flokulan (NCYC-1195), (b) non-flokulan (Kyokai 7 NCYC-479) 
logaritmik karena terjadi katabolisme substrat dalam jumlah besar yang digunakan untuk pertumbuhan, sintesa enzim dan sintesa senyawa lainnya. Sel yeast mengubah gula dari medium pertumbuhannya menjadi biomassa yang menunjukkan pertumbuhan sel yang intensif. Bersamaan dengan proses ini, etanol dan $\mathrm{CO}_{2}$ diproduksi. Pada fase anaerobik sel yeast menggunakan gula untuk sintesis etanol (Rankovic dkk., 2009). Berdasarkan Gambar 4 dapat diketahui bahwa sel flokulan dan non-flokulan selama proses fermentasi mempunyai berat kering sel yang hampir sama, walaupun jumlah sel antar kedua sel sangat berbeda dimana jumlah flokulan yeast lebih tinggi $1,6 \times 10^{9}$ dibandingkan jumlah sel non-flokulan yeast $4,2 \times 10^{8}$ $\mathrm{cfu} / \mathrm{ml}$ pada jam ke 24 (data tidak disajikan). Sehingga bisa dikatakan bahwa sel flokulan (NCYC-1195) mempunyai berat kering sel yang lebih rendah jika dibandingkan dengan sel non-flokulan (Kyokai 7 NCYC479). Hal ini bisa dikonfirmasi dengan hasil pengamatan sel flokulan dan non-flokulan menggunakan mikroskop cahaya (Gambar 1), dimana pada pengamatan tersebut terdapat perbedaan morfologi yaitu sel flokulan mempunyai bentuk yang lebih kecil jika dibandingkan dengan sel non-flokulan. Ukuran yang kecil inilah kemungkinan yang menyebabkan berat sel flokulan lebih ringan, sehingga walaupun pertumbuhan jumlah sel flokulan lebih tinggi daripada sel non-flokulan, berat kering sel flokulan tidak terpaut jauh dengan berat kering sel non-flokulan yang mempunyai jumlah sel lebih sedikit. Lebih lanjut, dari hasil penelitian ini terlihat bahwa pola pertumbuhan sel yeast pada produksi etanol berbeda jika dibandingkan dengan pola pertumbuhan yeast pada kurva pertumbuhan yang disajikan Gambar
2. Hal ini disebabkan oleh perbedaan medium yang digunakan yaitu pada saat produksi etanol medium yang digunakan adalah nira kelapa sawit dimana komponen yang terkandung didalamnya berbeda dibanding komponen pada medium sintetik yang digunakan untuk mengetahui kurva pertumbuhan yeast. Pada yeast nonflokulan digunakan medium sintetik YPD (glukosa $20 \mathrm{~g} / \mathrm{L}$, yeast extract $10 \mathrm{~g} / \mathrm{L}$, pepton $20 \mathrm{~g} / \mathrm{L}$ ), sedangkan untuk yeast flokulan ditumbuhkan pada medium sintetik $\mathrm{YM}$ (glukosa $10 \mathrm{~g} / \mathrm{L}$, yeast extract $3 \mathrm{~g} / \mathrm{L}$, pepton $5 \mathrm{~g} / \mathrm{L}$, malt extract $3 \mathrm{~g} / \mathrm{L}$ ). Data menunjukkan bahwa pertumbuhan yeast non-flokulan lebih tinggi dibanding pertumbuhan yeast flokulan karena kandungan glukosa, yeast extract dan pepton pada medium sintetik YPD jauh lebih tinggi dibanding pada medium sintetik YM.

\section{Pengaruh Penambahan Urea Terhadap Produksi Etanol oleh Flokulan Saccharomyces cerevisiae NCYC-1195 dan Non-flokulan Saccharomyces cerevisiae Kyokai 7 NCYC-479}

Pengaruh penambahan urea terhadap produksi etanol oleh Saccharomyces cerevisiae NCYC-1195 (flokulan) dan Kyokai 7 NCYC-479 (non-flokulan) ditunjukkan pada Gambar 5.

Berdasarkan data tersebut bisa diketahui bahwa dari semua konsentrasi urea yang ditambahkan $(0,1 \%$; 0,2\%; dan 0,3\%) pada medium fermentasi nira, baik yang difermentasi oleh Saccharomyces cerevisiae NCYC1195 maupun Kyokai 7 NCYC-479 mempunyai tren produksi etanol yang sama terhadap medium fermentasi tanpa diperkaya urea (0\%). Hal ini membuktikan bahwa konsentrasi urea tidak berpengaruh terhadap jumlah etanol yang dihasilkan. Fenomena ini diduga bahwa

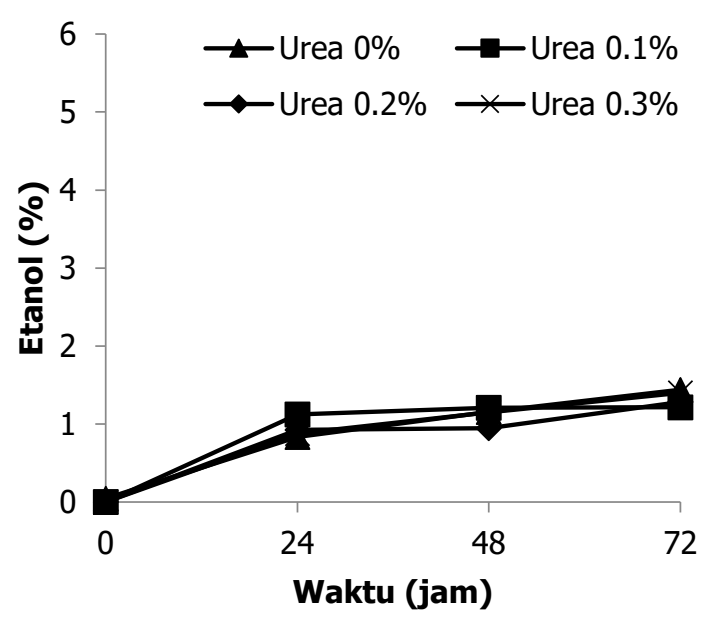

a)

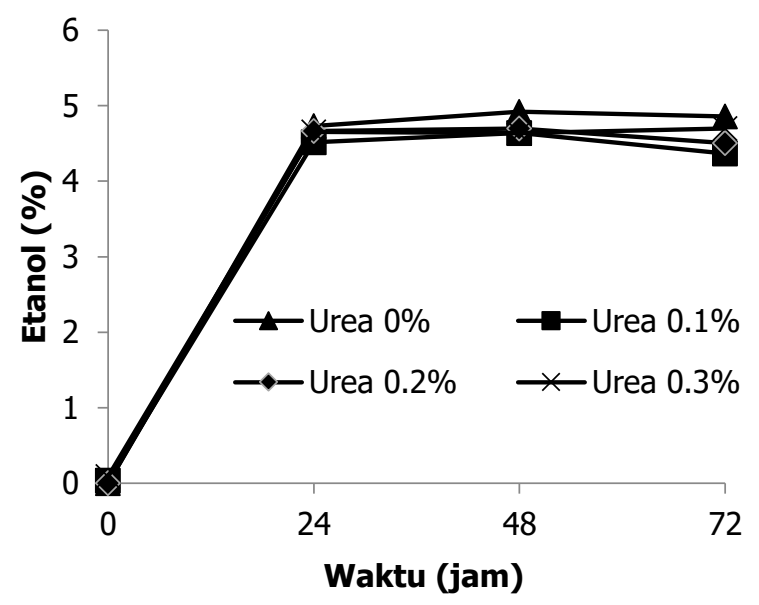

b)

Gambar 5. Pengaruh penambahan urea terhadap produksi etanol oleh Saccharomyces cerevisiae (a) flokulan (NCYC-1195), (b) non-flokulan (Kyokai 7 NCYC-479) 
kebutuhan nitrogen untuk pertumbuhan sel sudah terpenuhi oleh asam amino yang terdapat pada nira batang kelapa sawit. Kosugi (2010) melaporkan nira batang kelapa sawit tidak hanya kaya gula, tetapi juga mengandung asam amino, asam organik, vitamin dan mineral. Total asam amino pada nira ini mencapai 198,3 ( $\boldsymbol{\mu g} / \mathbf{g}$ nira) dengan serin, alanin, asam glutamat dan asam aspartat sebagai asam amino yang dominan. Pada akhir fermentasi nira batang kelapa sawit oleh Saccharomyces cerevisiae NCYC-1195 (flokulan) etanol tertinggi diperoleh sebesar $1,44 \%$ yang dihasilkan oleh kontrol atau fermentasi nira tanpa adanya penambahan urea $(0 \%)$ dan diikuti oleh perlakuan penambahan urea konsentrasi $0,3 \% ; 0,2 \%$ dan $0,1 \%$ dihasilkan etanol berturut-turut yaitu $1,40 \%, 1,28 \%$, dan $1,21 \%$. Hal serupa juga terjadi pada akhir fermentasi nira batang kelapa sawit oleh Saccharomyces cerevisiae Kyokai 7 NCYC-479 (non-flokulan). Pada penggunaan strain ini produksi etanol tertinggi sebesar $4,86 \%$ yang dihasilkan oleh fermentasi nira tanpa adanya penambahan urea (0\%) dan diikuti oleh perlakuan penambahan urea dengan konsentrasi $0,3 \%$; $0,2 \%$; dan $0,1 \%$ dengan hasil etanol berturut-turut sebesar 4,70\%, 4,50\% dan $4,37 \%$. Peningkatan konsentrasi urea yang ditambahkan dalam medium nira berdampak pada penurunan kadar etanol yang dihasilkan, sehingga dalam hal ini dapat disimpulkan bahwa urea bersifat sebagai inhibitor. Hasil penelitian ini sejalan dengan pendapat Garraway dan Evans (1984) yang menyatakan pada penambahan konsentrasi urea yang lebih tinggi selama fermentasi akan diurai menjadi amonia dan karbondioksida, yang selanjutnya akan digunakan oleh mikroorganisme untuk pembentukan sel. Hendriksen dan Ahrig (1991) menambahkan, produksi amonia dari urea mempunyai kecepatan empat kali lebih besar dari pembentukan sel mikroorganisme sehingga konsentrasi amonia akan tinggi yang selanjutnya bersifat toksik untuk proses fermentasi itu sendiri. Selanjutnya Utami dkk. (2000) mengemukakan bahwa penambahan sumber nitrogen yang berlebih akan berakibat penurunan produksi etanol karena bersifat sebagai inhibitor. Hermawan dkk. (2000) menyebutkan bahwa konsentrasi dan sumber nitrogen akan mempengaruhi nilai $\mathrm{pH}$ medium, pertumbuhan dan aktivitas mikroorganisme dalam proses fermentasi. Penurunan $\mathrm{pH}$ dapat menghambat proses fermentasi, hal ini disebabkan karena enzim penghasil etanol aktif pada interval pH tertentu. Penelitian Okti (2009) memperlihatkan penurunan kadar etanol yang dihasilkan setelah melampaui kondisi optimum, dikarenakan sebagian sel mati akibat tingginya konsentrasi nitrogen yang menyebabkan protein sel terdenaturasi. Jika terjadi denaturasi sel maka produktivitas enzim pun mengalami penurunan sehingga etanol yang dihasilkan lebih rendah. Hal ini menunjukkan bahwa urea sebagai sumber nitrogen cenderung digunakan untuk pembentukan biomasa. Respon penambahan urea terhadap produksi etanol untuk masing-masing strain yang digunakan menunjukkan hasil yang sama, tetapi jika respon produksi etanol kedua strain dibandingkan akan tampak berbeda. Secara keseluruhan produksi etanol oleh Saccharomyces cerevisiae Kyokai 7 NCYC479 (non-flokulan) lebih tinggi jika dibandingkan dengan Saccharomyces cerevisiae NCYC-1195 (flokulan). Perbedaan ini dimungkinkan bisa terjadi karena kedua strain mempunyai perbedaan kemampuan asimilasi nitrogen, toleransi terhadap lingkungan fermentasi dan ketahanan terhadap etanol. Rendahnya etanol pada fermentasi nira oleh NCYC-1195 (flokulan) dapat dipengaruhi oleh beberapa faktor, salah satunya adalah jumlah sel yang ditambahkan pada awal fermentasi yaitu $\pm 1 \times 10^{7} \mathrm{cfu} / \mathrm{ml}$ terhitung tinggi untuk strain ini, akibatnya gula pada nira sebagian besar habis digunakan untuk pertumbuhan sel dan sisanya dirombak menjadi etanol. Hal ini bisa dikonfirmasi dengan melihat Gambar 3, yaitu tren konsumsi gula NCYC-1195 (flokulan) sama dengan tren konsumsi gula pada Kyokai 7 NCYC-479 (non-flokulan), tetapi petumbuhan jumlah sel keduanya berbeda, yaitu pada NCYC-1195 (flokulan) jumlah sel yang dihasilkan jauh lebih besar jika dibandingkan dengan Kyokai 7 NCYC-479 (non-flokulan). Khongsey dkk. (2010) menyatakan jumlah sel yang besar pada awal fermentasi mengakibatkan terjadinya kompetisi substrat untuk pertumbuhan sel sehingga jumlah sumber karbon yang tersedia untuk dikonversi menjadi etanol lebih sedikit atau bahkan sudah habis dan etanol yang dihasilkan menjadi lebih rendah. Mukhtar dkk. (2010) menambahkan bahwa dalam pembuatan etanol, inokulasi yeast yang terlalu tinggi menyebabkan proses melemah lebih cepat dan menurunkan viabilitas sel setelah fase pertumbuhan. Kondisi pertumbuhan dan metabolisme pada populasi sel yang tinggi tidak diharapkan karena mengganggu akses nutrisi, keterbatasan ruang, dan interaksi antar sel.

\section{Penentuan Perlakuan Terbaik Fermentasi Nira Batang Kelapa Sawit}

Penentuan perlakuan terbaik pada produksi etanol dari nira batang kelapa sawit menggunakan Saccharomyces cervisiae Kyokai 7 NCYC-479 dan NCYC1195 dipilih berdasarkan produksi etanol tertinggi. Tabel 1 merupakan data lengkap hasil produksi etanol yang dipengaruhi oleh variasi konsentrasi urea dan strain Saccharomyces cerevisiae.

Berdasarkan Tabel 1, perlakuan nira batang kelapa sawit tanpa adanya penambahan urea yang difermentasi oleh Saccharomyces cerevisiae Kyokai 7 
Tabel 1. Pengaruh konsentrasi urea dan strain Saccharomyces cerevisiae terhadap produksi etanol

\begin{tabular}{lcccc}
\hline \multirow{2}{*}{ Strain S. cerevisiae } & \multicolumn{4}{c}{ Konsentrasi urea (\% b/v) } \\
\cline { 2 - 5 } & 0 & 0,1 & 0,2 & 0,3 \\
\hline $\begin{array}{l}\text { Kyokai 7 NCYC-479 } \\
\text { (non-flokulan) }\end{array}$ & 4,855 & 4,369 & 4,502 & 4,698 \\
NCYC-1195 (flokulan) & 1,440 & 1,216 & 1,283 & 1,400 \\
\hline
\end{tabular}

NCYC-479 (non-flokulan) merupakan perlakuan terbaik dalam penelitian ini karena mampu menghasilkan etanol paling tinggi sebesar 4,86 \%. Profil fermentasi perlakuan terbaik ditunjukkan pada Gambar 6 .

Dari Gambar 6 dapat dilihat tren penurunan kadar gula medium fermentasi dan peningkatan OD sel serta etanol yang dihasilkan. Penurunan kadar gula reduksi terjadi secara signifikan pada jam ke-24 yaitu dari $10,080 \%$ menjadi $1,41 \%$ dan jam selanjutnya penurunan kadar gula cenderung tidak begitu besar. Pada akhir fermentasi gula pada nira menjadi 0,69\%. Seiring dengan adanya penurunan kadar gula reduksi, OD sel mengalami peningkatan. Adanya penurunan kadar gula reduksi dan peningkatan OD sel tersebut mengindikasikan bahwa Saccharomyces cerevisiae Kyokai 7 NCYC-479 mengkonsumsi gula tersebut untuk pertumbuhan sel dan aktivitas metabolismenya. Peningkatan OD sel terjadi secara drastis pada jam ke24 dari OD sel 0,687 pada jam ke-0 menjadi 21,77 pada jam ke-24 (fase eksponensial). Pada jam ke-48 dan 72, OD sel juga mengalami peningkatan, tetapi tidak begitu besar. Selama fase eksponensial, Saccharomyces cerevisiae Kyokai 7 NCYC-479 mengubah gula dari medium pertumbuhannya menjadi biomasa dengan meningkatnya pertumbuhan sel. Bersamaan dengan proses ini, etanol dan $\mathrm{CO}_{2}$ diproduksi. Produksi etanol

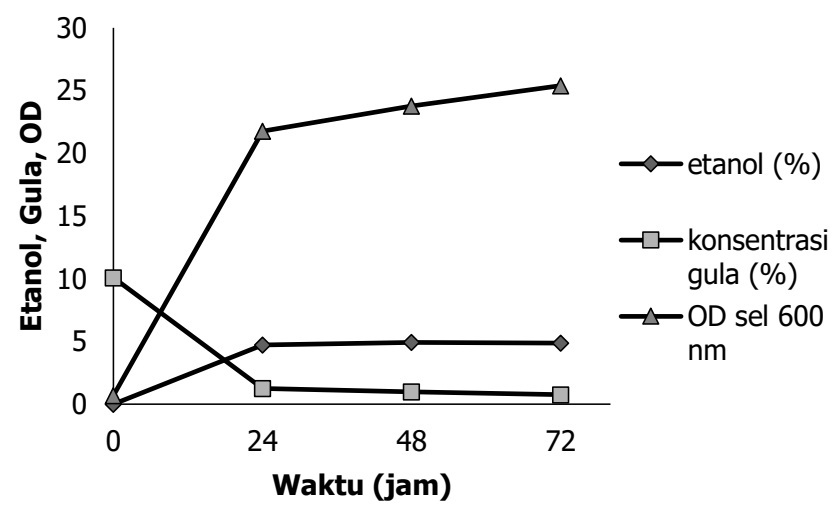

Gambar 6. Profil fermentasi perlakuan terbaik oleh Saccharomyces cerevisiae Kyokai 7 NCYC-479 (non-flokulan) mengalami kenaikan pada jam ke-24 yaitu sebesar $4,73 \%$ dan terus meningkat hingga $4,86 \%$ pada jam ke-72.

Hasil perhitungan yield etanol perlakuan terbaik adalah $0,52(\mathrm{~g} / \mathrm{g})$, tingginya yield yang diperoleh menyatakan bahwa proses fermentasi pada penelitian ini telah efisien. Najafpour and Lim (2002) menunjukkan yield maximum etanol oleh yeast sebesar $0,51 \mathrm{~g}$ etanol/g glukosa atau $51 \%$ yang dihitung melalui reaksi stoikiometri.

\section{KESIMPULAN}

Nira batang kelapa sawit sebagai limbah hasil perkebunan kelapa sawit berpotensi sebagai substrat alternatif yang murah untuk memproduksi etanol. Produksi etanol tertinggi yaitu 4,86\% (b/v) diperoleh pada fermentasi nira batang kelapa sawit dengan inokulum Saccharomyces cerevisiae Kyokai 7 NCYC479 (non-flokulan) tanpa adanya penambahan urea. Fermentasi etanol berjalan dengan efisien karena yield etanol yang dihasilkan sebesar 0,52 ( $\mathrm{g} / \mathrm{g})$.

\section{UCAPAN TERIMA KASIH}

Penulis mengucapkan terima kasih kepada PT. Sampoerna Agro, Tbk dan Fakultas Teknologi Pertanian atas kontribusinya berupa bantuan pendanaan penelitian.

\section{KONFLIK KEPENTINGAN}

Peneliti menyampaikan bahwa dalam penelitian ini tidak ada konflik kepentingan (conffict of interest) dari berbagai pihak.

\section{DAFTAR PUSTAKA}

Ain, N. (2010). Study on Bioethanol Productionfrom Oil Palm Trunk Sap. Faculty of Chemical \& Natural Resources Engineering. Universiti Malaysia Pahang. Malaysia.

Alauddin, Z.A.B.Z., Lahijani P., Mohammadi M., and Mohamed A.R. 2010. Gasification of lignocellulosic biomass in fluidized bed for renewable energy development: a review. Renewable and Sustainable Energy Reviews. 14: 2852-2862.

Aisyah, S.N dan Sembiring, K.C. 2009. Bioproses dan Teknologi Pembuatan Bioetanol. Berita IPTEK LIPI. Tahun ke47(1): 64-71.

Anonymous. 2013. Ethanol Fuel. http://en.wikipedia.org. Diakses tanggal 16 Agustus 2016. 
Apriyantono, A., D. Fardiaz, N. L. Puspitasari, Sedarnawati dan Budiyanto.1989. Analisa Pangan. PAU Pangan dan Gizi. IPB. Bogor

Azhar, S H M., Abdulla R, JamboSA., Marbawi H, Gansau J A., Faik A A M., Rodrigue, K F. 2017. Yeasts in sustainable bioethanol production: A review. Biochemistry and Biophysics Reports. Biochemistry and Biophysics. 10:5261.

Badan Pusat Statistik. Perkembangan Jumlah Kendaraan Bermotor menurut Jenis tahun 1987-2012. www.bps. go.id. Diakses tanggal 23 Oktober 2017.

Badan Pusat Statistik. Produksi Bahan Bakar Minyak 1996-2017. https://www.bps.go.id/dynamictable/2016/01/28/1125/ produksi-bahan-bakar-minyak-bbm-1996-2015.html. Diakses tanggal 3 Juli 2019.

Bai, F.W, W.A. Anderson, M. Moo-Young. 2008. Ethanol fermentation technologies from sugar and starch feedstocks. Biotechnology Advances. Vol. 26:89-105.

Baig MMV, Mane VP, More DR, Shinde LP, Baig MIA. 2003. Utilization of Agricultural Waste of Banana: Production of Cellulases by Soil fungi, J. Environ. Biol. 24:173 -176.

Domingues.L, A.A Vicente, N. Lima, J.A Teixeira. 2000. Applications of yeast flocculation in biotechnological processes. Biotechnol. Bioprocess Eng. Vol.5: 288-305.

Demain, A.L., Newcomb, M., and Wu, J.H.D. 2005. Cellulase, Clostridia, and Ethanol. Microbiology and Molecular Biology Reviews. 69: 124-154

Direktorat Jenderal Minyak dan Gas Bumi Kementerian Energi dan Sumber Daya Mineral 2017. Statistik Minyak dan Gas Bumi Tahun 2016. Jakarta.

Erten H., H. Tanguler, T. Cabaroglu., A. Canbas. 2006. The Influence of Inoculum Level on Fermentation and Flavour Compounds of White Wines Made from cv. Emir. J. Inst. Brew. 112(3):232-236

Forgacs, E. And Cserhati, T. 2003. Gas Chromatography. Woodhead Publishing Limited and CRC Press LLC. New York

Gancedo, J.M. 1998. Yeast Carbon Catabolite Repression. Microbiology and Molecular Biology Reviews. Vol. 62(2): 334-361.

Guritno P, Darnoko D. 2003. Teknologi Pemanfaatan Limbah Dari Peremajaan Perkebunan Kelapa Sawit. Seminar Nasional: Mengantisipasi Regenerasi Pertama Perkebunan Kelapa Sawit di Indonesia 9 - 10 April 2003. Bali: Max Havelaar Indonesia Foundation.

Harris, Sjamsjul Anam, dan Syarifuddin Mahmudsyah.2013. Studi Pemanfaatan Limbah Padat dari Perkebunan Kelapa Sawit pada PLTU 6 MW di Bangka Belitung. Jurnal Teknik Pomits Vol. 2, No. 1, (2013) ISSN: 2337-3539.

Hendriksen, H.V. and Ahring, B.K. 1991. Effects of ammonia on growth and morphology of thermophilic hydrogen- oxidizing methanogenic bacteria. FEMS Microbila Ecology. 85: 241-246

Hermawan, D. R. W. A., Utami., T. dan Cahyanto, M. N., 2000. Fermentasi Etanol dari Buah Semu Jambu Mete (Anacardium occidentale L.) oleh Saccharomyces cereviseae FNCC 3015 Menggunakan Ammonium Sulfat dan Urea Sebagai Sumber Nitrogen. Agritech. 20(2): $93-98$.

Indartono, Y. 2005. Bioetanol Alternatif Energi Terbarukan: Kajian Prestasi Mesin dan Implementasi di Lapangan. www.energi.lipi.go.id. Diakses tanggal 26 september 2016.

Jennifer, C.B. 2005. Characteristics of Flo11-dependent Flocculation in Saccharomyces cerevisiae. FEMS Yeast Res. 5 (2005) 1151-1156.

Kida, K., Morimura S., Kume K., Suruga K., and Sonoda Y. 1991. Repeated batch ethanol fermentation by a flocculating yeast Saccharomyces cerevisiae IR-2. J. Ferment Bioeng. 71:340-344.

Khongsay, N., Lakkana, L. And Pattana, L. 2010. Growth and Batch Ethanol Fermentation of Saccharomyces cerevisiae on Sweet Sorghum Stem Juice under Normal and Very High Gravity Condition. Biotechnol. 9(1): 9-16

Kosugi, A., Tanaka, R., Magara, K., Murata, Y., dkk. 2010. Ethanol and lactic acid production using sap squeezed from oil palm trunks felled for replanting, Journal of Bioscience and Bioengineering, vol. 110, no. 3, pp. 322325, 2010.

Lin, Y.H, W.S Chien, K.J Duan, and P.R Chang. 2011. Effect of Aeration Timing and Interval During Very High Gravity Ethanol Fermentation. Process Biochemistry. Vol. 46:1025-1028.

Madigan, M.T, Martinko, J.M, and Parker, J. 2000. Nutirition and metabolism Brock biology of microbiology. 9th. ed. $\mathrm{NJ}$ : prentice-Hall.

Maurice, M. L. 2011. Factors Effecting Ethanol Fermentation Via Simultaneous Saccharification and Fermentation. Major Qualifying Project for the Gegree of Bachelor Science.Worcester Polytechnic Science.

Maiorella. 1985. Ethanol. Comprehensive Biotechnology. Vol.3 Pergamon.

Michael, H. L., W. R. James., L. O Joe., T. H. Mark, and F.O. Rene. 2006. The Economics of Ethanol from Sweet Sorghum Using the MixAlco Process. http://www.afpc. tamu.edu/pubs/2/446/RR\%2006-2.pdf. Tanggal akses 20 Agustus 2014.

Miki, B.L.A., Poon, N.H., James, A.P., Seligy, V.L. 1982. Possible mechanism for flocculation interactions governed by gene FLO1 in Saccharomyces cerevisiae. J Bacteriol 150,878-889 
Miller, G.L. 1959. Use of Dinitrosalicylic Acid Reagent for Determination of Reducing Sugar. Anal Chem. 31: 426.

Mori, Yutaka.2007. Old Oil Palm Trunks as Promising Feedstock for Biofuel and Bioplastics. University of Science Malaysia and Forest Research Institute Malaysia. 4" BMWS 2007.

Mukhtar, K., M. Asgher, S. Afghan, K. Hussain, and S. Zia-ul-Hussnain. 2010. Comparative Study on Two Commercial Strains of Saccharomyces cerevisiae for Optimum Ethanol Production on Industrial Scale. J. Biomed. Biotechnol. 2010: 5

Naik, S.N., V.V. Goud, P.K. Rout., A.K. Dalai. 2010. Production of first and second generation biofuels: A comprehensive review. Renewable and Sustainable Energy Reviews. Vol. 14: 578-597.

Nofemele, Z, Pratyoosh Shukla, Arthur Trussler, Kugen Permaul, and Suren Sigh. 2012. Improvement of Ethanol Production from Sugarcane Molasses through enhanched nutrient Supplementation using Saccharomyces cerevisiae. Journal of Brewing and Distillatilling 3(2): 29-35.

Quintero, J.A., V. 2006. Palm sugar: the Indigeneous Sweetness. ILEIA Newslett. 13(2): 19

Richana, Nur dan Suarni. 2008. Teknologi Pengolahan Jagung. Balai Besar Penelitian dan Pengembangan Pasca Panen. Bogor.

Samejima, M. 2008. Scenario of Technical Innovation for Production of Ethanol as Automobile Fuel from Cellulosic Biomass in Japan. Proceedings International Symposium on Wood Scienceand Technology. Harbin, China, 27-29 Sep 2008. Harbin: Iternational Association of Wood Products Societies.

Soares, E.V. 2010. Flocculation of Saccharomyces cerevisiae : a Review. Journal of Applied Microbiology ISSN 13645072. Vol.110: 1-18.
Sukumaran, R.K., dkk. 2008. Cellulase Production Using Biomassa Feed Stock and Its Application in Lignocellulosa Saccharification for Bioethanol Production. Renewable Energy.Vol. 30: 1-4.

Sultana, S., Mohd Jamil1, N., Saleh, E A M, Yousuf, A., and Faizal, C.K.M. 2017. A mathematical model for ethanol fermentation from oil palm trunk sap using Saccharomyces cerevisiae. J. Phys.: Conf. Ser. 890 012050. 1-6.

Suriyachai N., K. Weerasaia, N. Laosiripojana, V. Champreda, 2013. Optimized simultaneous saccharification and cofermentation of rice straw for ethanol production by Saccharomyces cerevisiae and Scheffersomyces stipitis co-culture using design of experiments. Bioresource technology 142: 171-178.

Tohari, A. 2012. Sekali lagi: Etanol dari Tebu. P3GI. Pasuruan.

Wahyuni. A. 2008. Rekayasa bioproses pembuatan bioetanol dari sirup glukosa ubi jalar (Ipomoea batatas $\mathrm{L}$ ) dengan menggunakan Saccharomyces cerevisiae.Thesis.Sekolah pasca Sarjana.IPB. Bogor.

Waites, MJ, Morgan, NL, John, SR, Gary, H. 2001. Industrial Microbiology an Introduction. Blackwell Publishing Company, Victoria Australia.

Wyman, C.E. 1999. Ethanol Production From Lignocellulosic Biomass: overview. CRC Press. Inc. Cleceland Ohio. Chapter 1:1-18

Yamada H., Tanaka R., Sulaiman O, Hashim R., Hamid, Z.A.A., Yahya M.K.A, Kosugi, A., Arai T. Murata Y., Nirasawa S, Yamamoto K., Ohara S., Yusof M N M., Ibrahim, W A., Mori Y. 2010. Old oil palm trunk: A promising source of sugars for bioethanol production. Biomass and Bioenergy. 34(11):1608-1613. 